NASA/CR- - 94- 207594

JoURNAL OF MOLECULAR

EVOLUTION

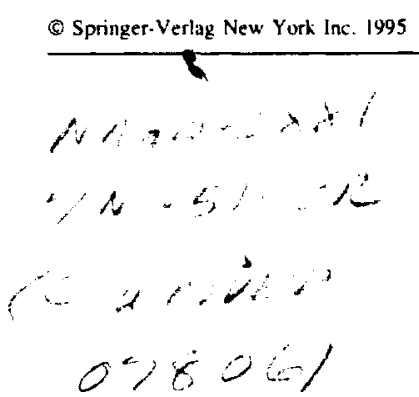

\title{
Self-Incorporation of Coenzymes by Ribozymes
}

\author{
Ronald R. Breaker, Gerald F. Joyce \\ Departments of Chemistry and Molecular Biology. The Scripps Research Institute, 10666 North Torrey Pines Road, La Jolla, CA 92037, USA
}

Received: 2 August 1994 / Accepted: 29 November 1994

\begin{abstract}
RNA molecules that are assembled from the four standard nucleotides contain a limited number of chemical functional groups, a characteristic that is generally thought to restrict the potential for catalysis by ribozymes. Although polypeptides carry a wider range of functional groups, many contemporary protein-based enzymes employ coenzymes to augment their capabilities. The coenzymes possess additional chemical moieties that can participate directly in catalysis and thereby enhance catalytic function. In this work, we demonstrate a mechanism by which ribozymes can supplement their limited repertoire of functional groups through RNAcatalyzed incorporation of various coenzymes and coenzyme analogues. The group I ribozyme of Tetrahymena thermophila normally mediates a phosphoester transfer reaction that results in the covalent attachment of guanosine to the ribozyme. Here, a shortened version of the ribozyme is shown to catalyze the self-incorporation of coenzymes and coenzyme analogues, such as $\mathrm{NAD}^{+}$and dephosphorylated CoA-SH. Similar ribozyme activities may have played an important role in the "RNA world," when RNA enzymes are thought to have maintained a complex metabolism in the absence of proteins and would have benefited from the inclusion of additional functional groups.
\end{abstract}

Key words: Tetrahymena thermophila - Group I intron - Self-splicing RNA - RNA world - Nicotinamide - Coenzyme $A$

Correspondence 1o: G.F. Joyce

\section{Introduction}

The first reports of RNA molecules with enzymatic activity (Kruger et al. 1982; Guerrier-Takada et al. 1983) confirmed earlier speculation that RNA could function as both genotype and phenotype (Woese 1967; Crick 1968; Orgel 1968). In the decade following these initial discoveries, additional ribozymes have been isolated from natural sources and have been characterized in detail (reviewed by Cech and Bass 1986; Symons 1992). However, these ribozymes catalyze a restricted range of chemical reactions, mainly phosphoester transfer or phosphoester hydrolysis. This observation has supported the view that RNA is hindered catalytically and lacks functional properties needed to catalyze more complex reactions. One obvious deficiency of RNA is that it is composed of only four different monomers, which carry a limited variety of chemical functional groups, and hence cannot be expected to catalyze as broad a range of reactions as are catalyzed by protein enzymes (Orgel 1968; Cech 1993).

It is becoming clear, however, that the catalytic potential of RNA is not limited to simple phosphoester chemistry. This view has been bolstered by the demonstration that RNA can catalyze the formation of a phosphoester by the splitting of a phosphoanhydride bond (Mörl et al. 1992; Bartel and Szostak 1993; Lorsch and Szostak 1994a) and can accelerate the hydrolysis of an aminoacyl ester (Piccirilli et al. 1992). In addition, it has been shown that highly deproteinized large-subunit ribosomal RNA retains much of the peptidyl transferase activity of the intact ribosome (Noller et al. 1992), thereby implicating RNA as the catalyst of peptide bond formation during protein synthesis. Most recently it was shown that RNA can catalyze the interconversion of two rota- 

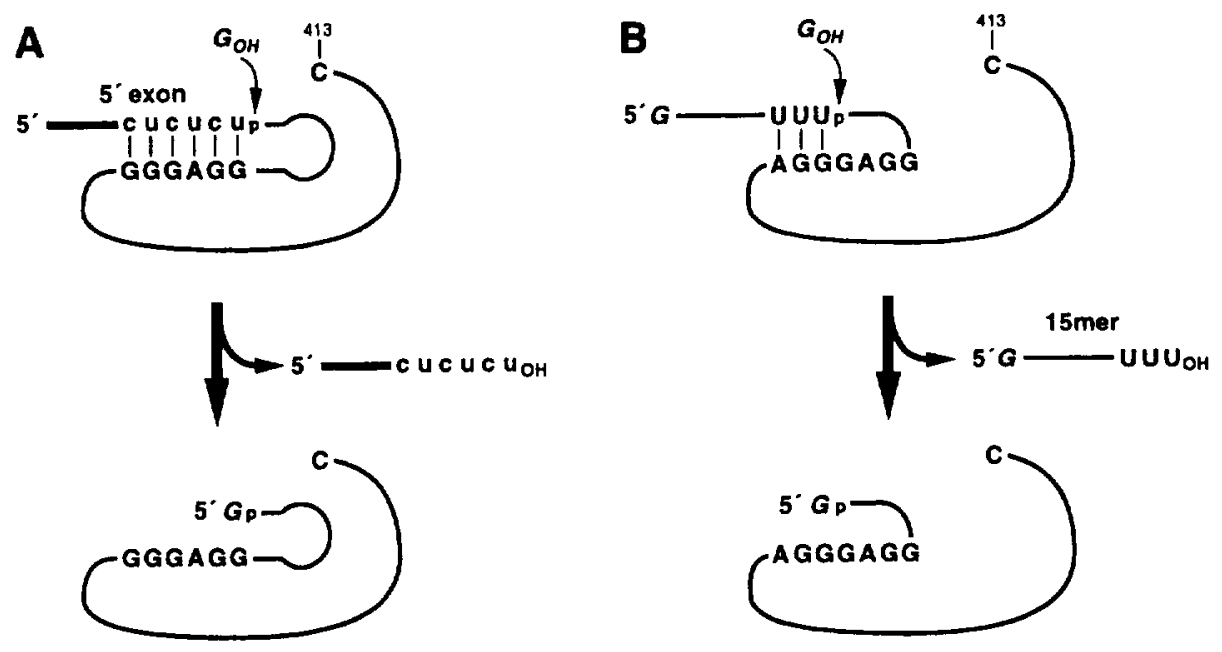

Fig. 1. Phosphoester transfer reactions occurring at the $5^{\prime}$ end of the Tetrahymena group I ribozyme. A Guanosine attacks the $5^{\prime}$ splice site. releasing the $5^{\prime}$ exon and forming a new phosphodiester linkage between guanosine and the $5^{\prime}$ terminus of the ribozyme. B A similar transesterification can occur 14 nucleotides downstream from the first site, resulting in covalent attachment of a second guanosine. (Figure adapted from Been et al. 1987).

tional isomers of a hindered biphenyl compound (Prudent et al. 1994) and can catalyze the cleavage of an amide bond (Dai et al. 1995).

RNA is proposed to have played a prominent role in the historical progression from prebiotic conditions on Earth to contemporary cellular life. The "RNA world" hypothesis suggests that, through the action of ribozymes, metabolic pathways were maintained by living systems in the absence of DNA and proteins (Gilbert 1986; Weiner 1987; Benner et al. 1989; Joyce 1991). RNA would have had to exploit both its informational and catalytic properties to the fullest in order to carry out many of the functions that are currently managed by DNA genomes and protein enzymes.

Evidence for the complexity of ribozyme-mediated metabolism in the RNA world was put forth by White (1976), who observed that most of the coenzymes of contemporary metabolism include nucleotide or nucleotidelike moieties, in addition to the chemical substituents that are involved in catalysis. Ribozymes may have maintained a complex metabolism with the aid of coenzymes, which served to enhance the catalytic potential of RNA. Coenzymes may have been utilized by ribozymes in either a noncovalent or covalent manner, analogous to protein enzymes, which employ coenzymes as either dissociable cofactors or attached prosthetic groups. RNA is known to be capable of binding tightly to various coenzymes, including cyanocobalamin, nicotinamide adenine dinucleotide $\left(\mathrm{NAD}^{+}\right)$, and flavine mononucleotide (Lorch and Szostak 1994b; Burgstaller and Famulok 1994). According to the RNA world hypothesis, ribozymes eventually were supplanted by their more efficient protein counterparts, but the basic chemical structure of the coenzymes appears to have been conserved over the course of evolution, allowing these molecules to fulfill similar catalytic roles in the context of contemporary protein enzymes. Certain nucleotidelike coenzymes thus can be viewed as molecular relics of biological catalysis in the RNA world.

One of the most extensively characterized ribozymes that is found in modern cells is the group I self-splicing RNA of Tetrahymena thermophila. (For a review see Cech 1990.) This ribozyme promotes its own excision from a pre-rRNA molecule by catalyzing two successive phosphoester transfer reactions, resulting in liberation of the ribozyme and joining of the flanking $5^{\prime}$ and $3^{\prime}$ exons. The initial transesterification reaction involves attack by the $3^{\prime}$ oxygen of guanosine on the phosphorus at the $5^{\prime}$ splice site (Fig. 1A). The $5^{\prime}$ exon is released from the pre-rRNA while guanosine becomes covalently attached to the $5^{\prime}$-terminus of the ribozyme via a $3^{\prime}, 5^{\prime}$ phosphodiester linkage. We have exploited this reaction to obtain ribozymes that self-incorporate nucleotidelike coenzymes into their own primary structure, resulting in molecules that carry a coenzyme prosthetic group in close proximity to their catalytic center.

\section{Materials and Methods}

Bacteriophage $T 7$ RNA polymerase was prepared as previously described (Davanloo et al. 1984) and was purified according to a modification of a procedure originally developed for SP6 RNA polymerase (Butler and Chamberlin 1982). Nucleosides (guanosine, adenosine, and $\mathrm{NMN}^{+}$) and coenzymes (NAD+, NGD, $\mathrm{COA}-\mathrm{SH}$, and dephosphorylated $\mathrm{COA}-\mathrm{SH})$ were obtained from Sigma.

Preparation of Ribozymes. Ribozymes were prepared by in vitro transcription of plasmid pT7-TTI A3 (Zaug et al. 1986; Joyce and Inoue 1989), which encodes the complete intron, 33 nucleotides of the natural $5^{\prime}$ exon, and 37 nucleotides of the $3^{\prime}$ exon from Tetrahymena thermophila large-subunit pre-rRNA. The ribozyme-encoding gene is located 15 nucleotides downstream from a $T 7$ promoter, which yields a transcription product containing a total of 48 nucleotides in the 5 ' exon domain. Plasmid DNA was linearized by digestion with $S c a I$ and transcribed in vitro to yield RNA products that terminate at nucleotide $\mathrm{C} 413$ of the intron. Transcription mixtures contained $50 \mathrm{mM}$ Tris- $\mathrm{HCl}$ (pH $7.5,23^{\circ} \mathrm{C}$ ), $15 \mathrm{~mm} \mathrm{MgCl}, 2 \mathrm{~mm}$ spermidine, $5 \mathrm{~mm} \mathrm{DTT}, 2 \mathrm{~mm}$ each rNTP, $25 \mathrm{U} / \mu \mathrm{l}$ T7 RNA polymerase, $0.005 \mathrm{U} / \mu \mathrm{l}$ inorganic pyrophosphatase, and either $30 \mu \mathrm{Ci}\left[\alpha{ }^{-32} \mathrm{P}\right] \mathrm{GTP}$ and $3 \mu \mathrm{g}$ linearized plasmid DNA in $30-\mu \mathrm{l}$ volume or $50 \mu \mathrm{Ci}\left[5,6-{ }^{3} \mathrm{H}\right] \mathrm{UTP}$ and $2.5 \mu \mathrm{g}$ linearized plasmid DNA in $50-\mu 1$ volume, which was incubated at $37^{\circ} \mathrm{C}$ for $2 \mathrm{~h}$ Transcription products were purified by denaturing $5 \%$ polyacrylamide 
gel electrophoresis and subsequent chromatography on Du Pont Nensorb 20 and were quantified by liquid scintillation counting.

Clearage/Ligation Reactions. Ribozyme-catalyzed cleavagel ligation reactions were carried out in the presence of $50 \mathrm{mM}$ Tris- $\mathrm{HCl}$ $\left(\mathrm{pH} 7.0\right.$ at $\left.23^{\circ} \mathrm{C}\right), 10 \mathrm{mM} \mathrm{MgCl}, 30 \mathrm{nM}\left[\alpha{ }^{32} \mathrm{P}\right]$-labeled ribozyme, and $\mathrm{I} \mathrm{mM}$ substrate in $25-\mu \mathrm{l}$ volume, incubated at $42^{\circ} \mathrm{C}$. Aliquots of $10 \mu \mathrm{l}$ were removed after 10- and 100-min incubation, quenched by the addition of $10 \mu \mathrm{l}$ gel-loading buffer ( $8 \mathrm{M}$ urea, $5 \mathrm{~mm}$ Tris-borate ( $\mathrm{pH} 8.3$ at $23^{\circ} \mathrm{C}$ ), $0.3 \mathrm{M}$ sucrose, $50 \mathrm{mM} \mathrm{Na} \mathrm{a}_{2}$ EDTA, $0.02 \%$ w/v xylene cyanol, and $0.02 \% \mathrm{w} / \mathrm{v}$ bromophenyl blue), and analyzed by denaturing $5 \%$ polyacrylamide gel electrophoresis followed by autoradiography. $\mathbf{k}_{\text {thts }}$ values for ribozyme activity in the presence of various substrates were obtained by removing aliquots at various times, visualizing the reaction products by autoradiography, and quantifying precursor and product RNAs by Cerenkov counting of corresponding bands that were excised from the gel. The fraction of precursor cleaved at each time was determined by comparing the molar ratio of the sum of the two cleavage products to the total amount of RNA. Initial reaction rates were obtained from the slope of a line fit by the least-squares method to the first three to four time points $(r>0.98)$.

Product Characterization. Cleavage-ligation reactions were cartied out in the presence of $30 \mathrm{nM}\left[{ }^{3} \mathrm{H}\right.$-uracil]-labeled precursor RNA and either $1 \mathrm{~mm}$ guanosine in $160-\mu \mathrm{l}$ volume incubated for $30 \mathrm{~min}$ or $1 \mathrm{mM}$ $\mathrm{NAD}^{+}$in $280-\mu \mathrm{l}$ volume incubated for $2 \mathrm{~h}$ under the conditions described above. Reactions were terminated by the addition of $\mathrm{Na}_{2}$ EDTA ( $50 \mathrm{mM}$ final concentration) and the RNA products were purified by precipitation with ethanol. The resulting pellet was resuspended in $\mathrm{H}_{2} \mathrm{O}$ to a final RNA concentration of $60 \mathrm{~mm}$ and aliquots were taken for determination of the chemical nature of the 5 -terminus of the various RNAs.

Removal of a terminal nucleoside that has both $2^{\prime}$ and $3^{\prime}$ hydroxyls exposed was carried out by oxidation of the vicinal hydroxyls followed by $\beta$-elimination of the modified nucleoside (Nadeau et al. 1984). A $10-\mu \mathrm{l}$ aliquot from the $\mathrm{NAD}^{+}$-dependent reaction, equivalent to 600 fmol of input precursor RNA, was mixed with $2.4 \mu \mathrm{l} 0.2 \mathrm{M} \mathrm{NaIO}_{4}$ and incubated on ice for $1 \mathrm{~h}$. Residual oxidant was quenched by adding 3.6 $\mu \mathrm{l} 0.2 \mathrm{M} \mathrm{L}$-methionine and incubating on ice for $20 \mathrm{~min}$. Finally, $10 \mu \mathrm{l}$ of a solution containing $1 \mathrm{M}$ cyclohexylamine- $\mathrm{HCl}$ and $0.25 \mathrm{M}$ HEPES (pH 8.0) was added and the mixture was incubated at $42^{\circ} \mathrm{C}$ for $1 \mathrm{~h}$. The RNA products were purified by chromatography on Du Pont Nensorb 20.

RNAs from the $\mathrm{NAD}^{+}$-dependent reaction were dephosphorylated by adding the equivalent of $600 \mathrm{fmol}$ of precursor RNA to a $100-\mu \mathrm{l}$ volume containing $50 \mathrm{~mm}$ Tris $-\mathrm{HCl}\left(\mathrm{pH} 8.5\right.$ at $\left.20^{\circ} \mathrm{C}\right), 0.1 \mathrm{mM}$ $\mathrm{Na}_{2}$ EDTA, and $0.1 \mathrm{U}$ calf intestine phosphatase (BoehringerMannheim), which was incubated at $37^{\circ} \mathrm{C}$ for $30 \mathrm{~min}$, after which a second aliquot of phosphatase was added and the incubation was repeated. The completed reaction mixture was extracted twice with phenol, then once with chloroform/isoamyl alcohol $(24: 1, v / v)$, and the RNAs were recovered by precipitation with ethanol. RNAs isolated from the phosphatase reaction, or untreated RNAs, were $\left[5^{\prime}-{ }^{32} \mathrm{P}\right]-$ labeled in a $50-\mu$ l reaction volume containing $50 \mathrm{~mm}$ Tris- $\mathrm{HCl}(\mathrm{pH} 7.5$ at $23^{\circ} \mathrm{C}$ ), $10 \mathrm{~mm} \mathrm{MgCl}_{2}, 5 \mathrm{mM}$ DTT, $0.1 \mathrm{~mm}$ spermidine, $0.1 \mathrm{~mm}$ EDTA, $10 \mu \mathrm{Ci}\left[\gamma_{-32} \mathrm{P}\right] \mathrm{ATP}$, and $2 \mathrm{U}$ T4 polynucleotide kinase (New England Biolabs), which was incubated at $37^{\circ} \mathrm{C}$ for $30 \mathrm{~min}$. The reactions were terminated by the addition of $50 \mu \mathrm{l}$ gel-loading buffer, and the RNA products were separated by $5 \%$ denaturing polyacrylamide gel electrophoresis and visualized by autoradiography.

\section{Results}

\section{Coenzyme Incorporation Reactions}

Group I ribozymes adopt a well-defined tertiary structure that specifically accommodates guanosine or any of its
5 -phosphorylated derivatives within a substrate binding pocket (Bass and Cech 1984) (Fig. 2A). The ribozyme recognizes guanosine by forming specific contacts with the Watson-Crick base-pairing face of the guanine moiety (Bass and Cech 1984) and with the $2^{\prime}$ and $3^{\prime}$ hydroxyls of the ribose moiety (Bass and Cech 1986). The former set of interactions is mediated by a particular G-C base pair (G264-C311), which is thought to form a Hoogsteen base-triple with the substrate guanosine (Michel et al. 1989). Changing this base pair to either A264-U311 or C264-G311 changes the substrate preference of the ribozyme to either 2-aminopurine nucleoside or adenosine, respectively (Michel et al. 1989; Been and Perrotta 1991). The wild-type ribozyme can utilize other nucleoside substrates, even without mutating this guanosine binding site, albeit with significantly reduced efficiency (Inoue et al. 1986).

We investigated the ability of the Tetrahymena group I ribozyme to incorporate alternative chemical groups into its own primary structure by replacing the guanosine substrate with natural coenzymes or coenzyme analogues that would likely be recognized by the guanosine binding site. The $5^{\prime}$ position of guanosine is not important for recognition by the ribozyme (Fig. 2A). As a result, novel chemical moieties might be placed at this position without significantly disrupting the ribozyme-mediated phosphoester transfer reaction. We examined several coenzymes, including $\mathrm{NAD}^{+}$, and coenzyme analogues, including nicotinamide guanine dinucleotide $\left(\mathrm{NGD}^{+}\right)$ and dephosphorylated CoA-SH (de-CoA-SH), each of which contains a nucleoside moiety with a chemical substituent attached to the $5^{\prime}$ position via a pyrophosphoryl linkage (Fig. 2B). The $3^{\prime}$ hydroxyl of the nucleoside is left free in order to serve as the nucleophile in the RNAcatalyzed phosphoester transfer reaction (Fig. 2).

We employed a truncated form of the ribozyme that includes a 48-nucleotide $5^{\prime}$ exon and 413 nucleotides of the intron, terminating one nucleotide short of the $3^{\prime}$ splice site (Fig. 1). Incubation of $\left[\alpha-{ }^{32} \mathrm{P}\right]$-labeled ribozyme (Pre; Fig. 3 ) in the presence of unlabeled guanosine results in the rapid appearance of a primary cleavage product (Clv; Fig. 3, lane 4), corresponding to attack by guanosine at the $5^{\prime}$ splice site. This initial product remains catalytically active and can undergo another phosphoester transfer reaction to yield a secondary cleavage product ( $\mathrm{Clv}^{\prime}$; Fig. 3, lane 5) that is approximately 15 nucleotides shorter than Clv. The secondary product, which comprises the major product after 100 min incubation, is the result of nucleophilic attack by a second guanosine on a different phosphodiester linkage that lies within the $5^{\prime}$ portion of the ribozyme (Fig. 1B) (Been et al. 1987).

In addition to guanosine, a number of other nucleosidelike compounds function with reasonable efficiency in the ribozyme-mediated phosphoester transfer reaction (Fig. 3). $\mathrm{NGD}^{+}$would be expected to function efficiently if the nicotinamide portion of the coenzyme analogue has 
A guanosine

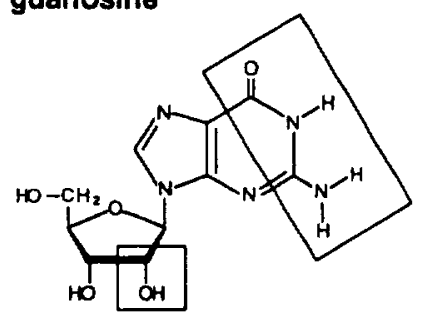

B

nicotinamide guanine dinucleotide $\left(\mathrm{NGD}^{+}\right)$

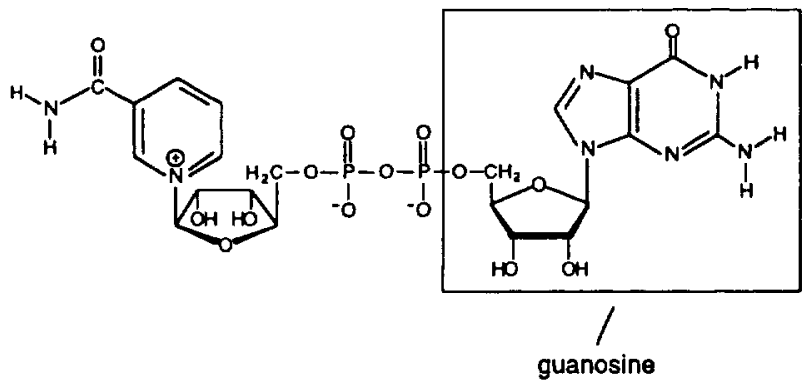

dephosphorylated COA-SH (de-CoA-SH)

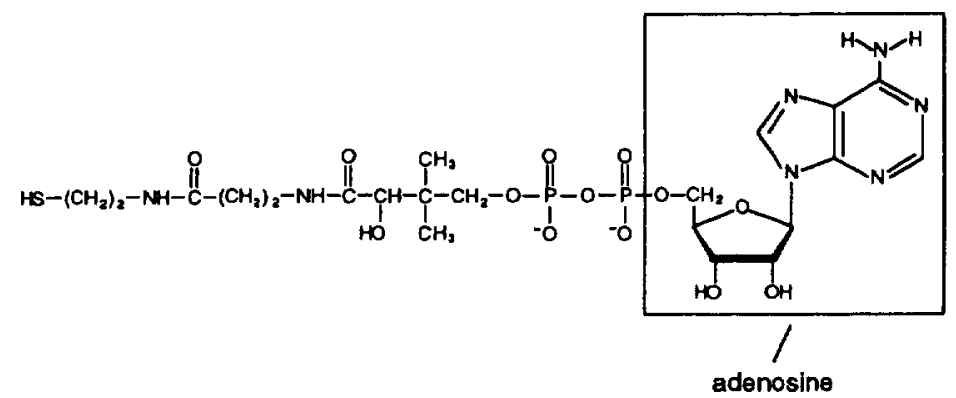

Fig. 2. Structures of (A) the natural group I ribozyme substrate (guanosine) and (B) the analogue substrates nicotinamide guanine dinucleotide $\left(\mathrm{NGD}^{+}\right)$and dephosphorylated CoA-SH (de-CoA$\mathrm{SH}$ ). Boxed regions in $\mathrm{A}$ show those portions of the molecule that are important for interaction with the ribozyme.

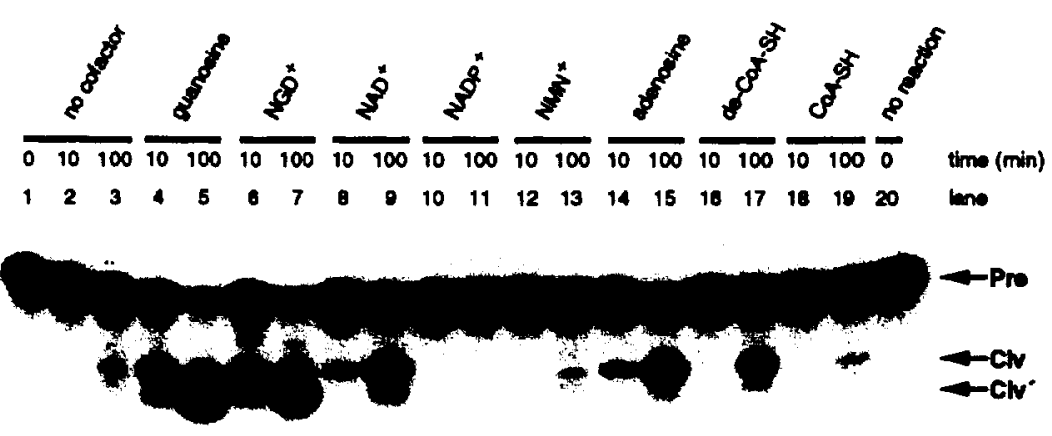

Fig. 3. Ribozyme-mediated phosphoester transfer reaction in the presence of various nucleoside, coenzyme, and coenzyme analogue substrates. Positions of precursor RNA (Pre) and the primary $(\mathrm{Clv})$ and secondary $\left(\mathrm{Cl} v^{\prime}\right)$ cleavage products are indicated. The primary and secondary cleavage reactions result in the release of free $5^{\prime}$ exon and 15 mer RNA, respectively, both of which have run off the bottom of the $5 \%$ polyacrylamide gel.

no effect on the interaction between the guanosine moiety and the ribozyme. Indeed, $\mathrm{NGD}^{+}$promotes the cleavage/ligation reaction with an efficiency comparable to that of guanosine (Fig. 3, lanes 6 and 7). Similarly, $\mathrm{NAD}^{+}$, adenosine, and de-CoA-SH also function in the ribozyme-catalyzed reaction, although with reduced efficiency. Substrates are rendered inactive if the nucleoside moiety is phosphorylated at either the $2^{\prime}$ hydroxyl $\left(\mathrm{NADP}^{+}\right)$or $3^{\prime}$ hydroxyl (CoA-SH). The relative efficiencies of each substrate were compared by determining initial rates of cleavage under a common set of reaction conditions (Table 1). The $\mathrm{k}_{\mathrm{obs}}$ for the ribozyme ranges from $-7 \times 10^{-2} \mathrm{~min}^{-1}$ in the presence of guanosine and $\mathrm{NGD}^{+}$to $-8 \times 10^{-4} \mathrm{~min}^{-1}$ in the presence of nicotinamide mononucleotide $\left(\mathrm{NMN}^{+}\right)$or with no added substrate $(-\mathrm{OH})$.

The guanosine or adenosine moiety of the various substrates is the most likely component to be recognized by the ribozyme. The $k_{\text {obs }}$ for the ribozyme in the presence of $\mathrm{NGD}^{+}$is similar to that for guanosine, while the 
Table 1. Reactivity of various substrates in the RNA-catalyzed selfincorporation reaction

\begin{tabular}{ll}
\hline Substrate & $\mathrm{k}_{\mathrm{ubs}} \times 10^{-3} \mathrm{~min}^{-\mathrm{ta}}$ \\
\hline Guanosine & 88 \\
$\mathrm{NGD}^{+}$ & 69 \\
$\mathrm{NAD}^{+}$ & 8.8 \\
Adenosine & 7.9 \\
de-CoA-SH & 4.5 \\
$\mathrm{NMN}^{+}$ & 0.83 \\
No substrate (-OH) & 0.73
\end{tabular}

"Values obtained from two replicates varied by $<10 \%$

$k_{\text {obs }}$ in the presence of either $\mathrm{NAD}^{+}$or de-CoA-SH is similar to that for adenosine (Table 1). Moreover, no significant amount of reactivity is observed in the presence of $\mathrm{NMN}^{+}$, suggesting that it is the riboguanosyl or riboadenosyl moiety of $\mathrm{NGD}^{+}$or $\mathrm{NAD}^{+}$, respectively, rather than the ribonicotinamide moiety, that acts as the nucleophile. It appears, therefore, that the ribozyme incorporates each substrate in an orientation-specific fashion, with the nicotinamide moiety of $\mathrm{NAD}^{+}$and $\mathrm{NGD}^{+}$or the sulfhydryl moiety of de-CoA-SH forming the $5^{\prime}$ terminus of the reacted ribozyme.

\section{Characterization of Cleavage/Ligation Products}

The products obtained by incubating the ribozyme in the presence of either guanosine or $\mathrm{NAD}^{+}$were analyzed in order to confirm the chemical nature of their $5^{\prime}$ termini, employing the strategy outlined in Fig. 4. Only those RNAs that acquire a free $5^{\prime}$ hydroxyl upon incubation with a substrate will be susceptible to enzymatic labeling with T4 polynucleotide kinase and $\left[\gamma_{-}^{32} \mathrm{P}\right] \mathrm{ATP}$. The precursor RNA carries a $5^{\prime}$-triphosphate moiety as a consequence of the in vitro transcription process, and thus cannot be $\left[5^{\prime}-{ }^{32} \mathrm{P}\right]$-labeled unless it is first treated with phosphatase to provide a free $5^{\prime}$ hydroxyl. Reaction products that have guanosine covalently attached to their $5^{\prime}$ end do not require a prior dephosphorylation step and can be labeled directly. Reaction products that have acquired $\mathrm{NAD}^{+}$cannot be $\left[5^{\prime}-{ }^{32} \mathrm{P}\right]$-labeled, even after treatment with phosphatase. In order to $5^{\prime}$ label these molecules, it is necessary to remove the nicotinamide mononucleoside portion of $\mathrm{NAD}^{+}$. This can be achieved by oxidizing the $2^{\prime}$ and $3^{\prime}$ hydroxyls with periodate and then carrying out $\beta$-elimination of the modified nucleoside (Fig. 4, step I). The resulting RNA product can then be dephosphorylated with phosphatase and subsequently 5 '-labeled with polynucleotide kinase (Fig. 4, steps II and III).

The results of a comparative $5^{\prime}$-end analysis of ribozyme, ribozyme reacted with guanosine, and ribozyme reacted with $\mathrm{NAD}^{+}$are shown in Fig. 5. Treatment of the unlabeled precursor RNA with phosphatase, followed by $\left[5^{\prime}-{ }^{32} \mathrm{P}\right]$ labeling with polynucleotide kinase, gives a ma- jor product corresponding to the ribozyme precursor (Pre; Fig. 5, lane 1), in addition to trace amounts of other products attributable to RNA degradation. Products of the phosphoester transfer reaction with guanosine are efficiently $\left[5^{\prime}-{ }^{32} \mathrm{P}\right]$-labeled without prior phosphatase treatment, while unreacted precursor that remains after the reaction can only be labeled if it is first dephosphorylated (Fig. 5, lanes 2 and 3 ). In contrast, the products of the reaction with $\mathrm{NAD}^{+}$cannot be $\left[5^{\prime}-{ }^{32} \mathrm{P}\right]$-labeled, even after prior treatment with phosphatase (Fig. 5, lanes 4 and 5). Their $5^{\prime}$ ends can only be labeled after first removing the terminal nicotinamide nucleoside and then treating with phosphatase (Fig. 5, lane 6).

\section{Discussion}

The experiments described above demonstrate the ability of a $3^{\prime}$-truncated version of a group I ribozyme to form a covalent linkage with various nucleoside-containing coenzymes and coenzyme analogues. The selfincorporation or, in principle, trans-incorporation of coenzymes into RNA can be used to diversify the structural and functional properties of RNA. The reactions that we have carried out are entirely consistent with the known catalytic properties of group I ribozymes. A precedent exists for the incorporation of modified nucleosides with pendant functional groups: guanosine analogues with a metal-chelating moiety linked to the $5^{\prime}$ hydroxyl have been shown to serve as substrates for a modified form of the Tetrahymena group I ribozyme (Wang and Cech 1992). Thus, we expected that the catalytic activity of this ribozyme could be utilized in a similar fashion to incorporate a variety of chemical groups at a specific site within the primary structure of the RNA.

The ribozyme accepts as substrates only coenzymes and coenzyme analogues that contain a nucleoside moiety in which those sites that are critical for binding and reactivity remain unobstructed. This is made evident by the fact that both $\mathrm{NADP}^{+}$and $\mathrm{CoA}$, which carry a $2^{\prime}$ or $3^{\prime}$ phosphate, respectively, are unable to function as substrates in the phosphoester transfer reaction (Fig. 3). The wild-type ribozyme prefers guanosine over adenosine, in the context of both the free nucleoside and the nucleoside-containing coenzymes. On the other hand, the 264C-311G ribozyme mutant, which prefers adenosine over guanosine in the context of the free nucleoside (Been and Perrotta 1991), is expected to favor adenosinecontaining coenzymes. It is somewhat surprising that the nicotinamide nucleoside moiety of $\mathrm{NMN}^{+}$or $\mathrm{NADP}^{+}$ cannot be accepted by the ribozyme, even at a very low level, under our chosen reaction conditions. It should be possible, however, to obtain mutant ribozymes that do accept nicotinamide-nucleoside substrates.

RNA is likely to be able to exploit bound or incorporated coenzymes to carry out a broader range of chemical 


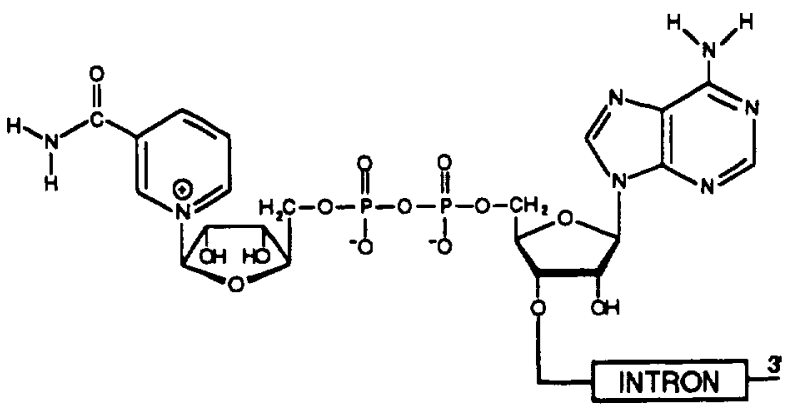

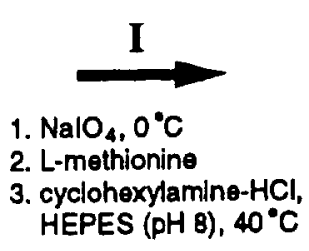

2. L-methionine HEPES (pH 8), $40^{\circ} \mathrm{C}$

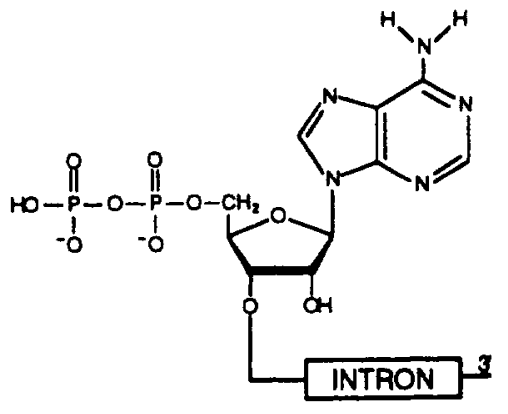

$\mathbf{I}$ phosphatase

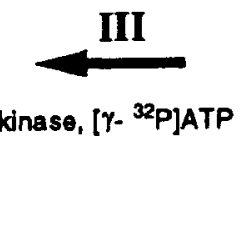

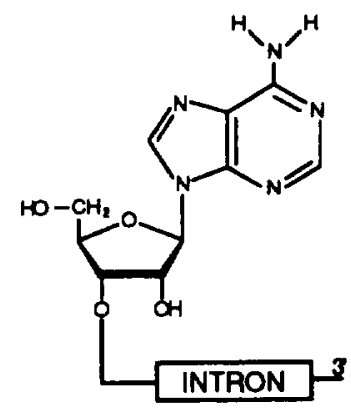

Fig. 4. Scheme for characterization of the $5^{\prime}$ terminus of reaction products resulting from the reaction of precursor RNA with NAD ${ }^{+}$

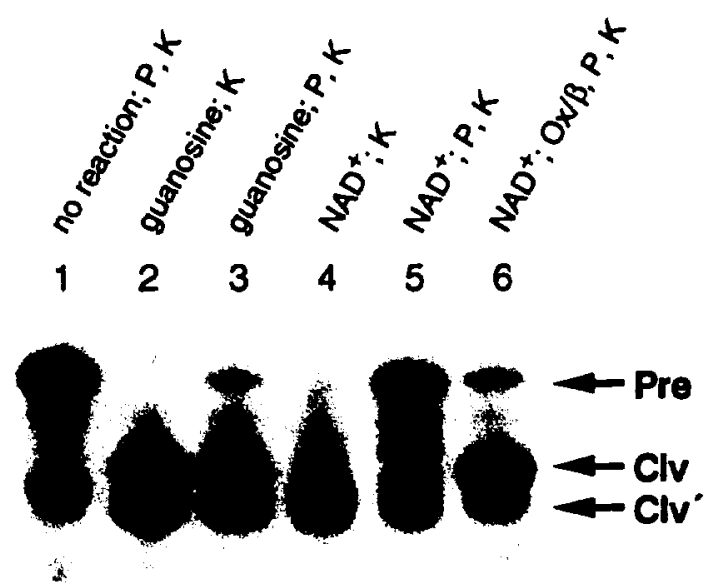

Fig. 5. Analysis of the 5' terminus of guanosine- and $\mathrm{NAD}^{+}$. dependent products of reacted precursor RNAs. Analytical treatments are calf intestine phosphatase $(P)$, polynucleotide kinase $(K)$, and periodate oxidation $/ \beta$-elimination $(O x / \beta)$. Positions of precursor RNA (Pre) and the primary $(\mathrm{Clv})$ and secondary $\left(\mathrm{Clv}^{\prime}\right)$ cleavage products are indicated.

reactions compared to standard RNA. The presence of nicotinamide in the RNA world, for example, may have enabled RNA to perform oxidation/reduction reactions. Several nicotinic acid derivatives, including nicotinamide, have been synthesized under conditions thought to resemble those of the primitive Earth (Dowler et al. 1970; Friedmann et al. 1971). Compounds carrying free or alkylated sulfhydryl groups might function as analogues of CoA or $S$-adenosyl methionine. Both cysteamine and pantothenic acid, the building blocks of CoA, can also be produced under simulated prebiotic conditions (Miller and Schlesinger 1993a,b) and may have served as primitive coenzymes. The problem remains to attach these primitive coenzymes to a nucleoside moiety in order to generate coenzyme structures akin to those found in modern cells, a catalytic task that presumably was once carried out by RNA. In the RNA world, there may have been a selective advantage in having the reactive portion of the coenzyme linked to a nucleoside so as to facilitate its incorporation into the primary structure of RNA.

The site-specific incorporation and subsequent utilization of coenzymes by ribozymes would likely have been selectively advantageous in the context of the RNA world. Not only would this have expanded the functional capacity of RNA, but also, because of the covalent attachment of the coenzyme, it would have ensured that this enhancement remained available despite environmental fluctuations that could deplete the local supply of coenzyme. By incorporating the coenzyme after, rather than during, RNA polymerization, the genetic role of RNA would be separated, to some extent, from its functional role. Thus, RNA polymerization need only be optimized with respect to incorporation of the four standard nucleotides, and subsequent RNA-catalyzed coenzyme 
incorporation could embellish the RNA without compromising its ability to be replicated.

Phosphoester transfer reactions involving coenzymes, comparable to those mediated by group I ribozymes, may have played a part in the physical maturation of ribozymes. For example, catalytic RNAs may have been produced in a precursor form and then, through a selfmaturation process, incorporated nucleotidelike coenzymes via a phosphoester transfer reaction. Alternatively, a class of "coenzyme-charging" ribozymes may have existed, which processed "preribozymes" through this same activity. As in contemporary ribozymes, the site or sites for coenzyme incorporation could be specified by a signal sequence that is recognized by a complementary template region within the charging ribozyme.

Ribozyme activities such as this may be useful in reinventing, through in vitro evolution (Szostak 1992; Joyce 1992; Breaker and Joyce 1994), various ribozyme activities that may have existed in the RNA world. It has been proposed (Sassanfar and Szostak 1993; Connell and Christian 1993) that new ribozymes can be created by first constructing pools of RNA that contain one or more small-molecule binding domains and then selecting for catalytic function that makes use of the bound small molecules (Lorsch and Szostak 1994a). RNAs that bind coenzymes in a noncovalent fashion (Lorsch and Szostak 1994b; Burgstaller and Famulok 1994) might be evolved to employ these cofactors in a catalytic role. Alternatively, one could construct pools of RNA molecules that contain recognition sequences that cause them to be covalently modified with a nucleoside-based coenzyme or coenzyme analogue through the activity of an existing ribozyme. These modified pools might then be evolved to exploit the coenzyme prosthetic group to perform novel RNA-catalyzed reactions.

Acknowledgments. This work was supported by NASA grant \#NAGW-3118.

\section{References}

Bartel DP, Szostak JW (1993) Isolation of new ribozymes from a large pool of random sequences. Science 261:1411-1418

Bass BL, Cech TR (1984) Specific interaction between the self-splicing RNA of Terrahymena and its guanosine substrate: implications for biological catalysis by RNA. Nature 308:820-826

Bass BL, Cech TR (1986) Ribozyme inhibitors: deoxyguanosine and dideoxyguanosine are competitive inhibitors of self-splicing of the Tetrahymena ribosomal ribonucleic acid precursor. Biochemistry 25:4473-4477

Been MD, et al. (1987) Structures involved in Tetrahymena rRNA self-splicing and RNA enzyme activity. Cold Spring Harbor Symp Quant Biol 52:147-157

Been MD, Perrotta AT (1991) Group I intron self-splicing with adenosine: evidence for a single nucleoside-binding site. Science 252: $434-437$
Benner SA, Ellington AD, Tauer A (1989) Modern metabolism as a palimpsest of the RNA world. Proc Natl Acad Sci USA 86:70547058

Breaker RR, Joyce GF (1994) Inventing and improving ribozyme function: rational design versus iterative selection methods. Trends Biotech 12:268-275

Burgstaller P. Famulok M (1994) Isolation of RNA aptamers for biological cofactors by in vitro selection. Angew Chem 33:1084-1087

Butler ET, Chamberlin MJ (1982) Bacteriophage SP6-specific RNA polymerase. J Biol Chem 257:5772-5778

Cech TR (1990) Self-splicing of group I introns. Annu Rev Biochem 59:543-568

Cech TR (1993) The efficiency and versatility of catalytic RNA: implications for an RNA world. Gene 135:33-36

Cech TR, Bass BL (1986) Biological catalysis by RNA. Annu Rev Biochem 55:599-629

Connell GJ, Christian EL (1993) Utilization of cofactors expands metabolism in a new RNA world. Orig Life 23:291-297

Crick FHC (1968) The origin of the genetic code. J Mol Biol 38:367379

Dai X, De Mesmaeker A, Joyce GF (1995) Cleavage of an amide bond by a ribozyme. Science $267: 237-240$

Davanloo P, Rosenberg AH, Dunn JJ, Studier FW (1984) Cloning and expression of the gene for bacteriophage T7 RNA polymerase. Proc Natl Acad Sci USA 81:2035-2039

Dowler MJ, Fuller WD, Orgel LE, Sanchez RA (1970) Prebiotic synthesis of propriolaldehyde and nicotinamide. Science 169:13201321

Friedmann N, Miller SL, Sanchez RA (1971) Primitive earth synthesis of nicotinic acid derivatives. Science 171:1026-1027

Gilbert W (1986) The RNA world. Nature 319:618

Guerrier-Takada C, Gardiner K, Marsh T, Pace N, Altman S (1983) The RNA moiety of ribonuclease $p$ is the catalytic subunit of the enzyme. Cell 35:849-857

Inoue T, Sullivan FX, Cech TR (1986) New reactions of the ribosomal RNA precursor of Tetrahymena and the mechanism of self-splicing. J Mol Biol 189:143-165

Joyce GF (1991) The rise and fall of the RNA world. New Biol 3:399407

Joyce GF (1992) Directed molecular evolution. Sci Am 267:90-97

Joyce GF. Inoue T (1989) A novel technique for the rapid preparation of mutant RNAs. Nucleic Acids Res 17:711-722

Kruger K, Grabowski PJ, Zaug AJ, Sands J, Gottschling DE, Cech TR (1982) Self-splicing RNA: autoexcision and autocyclization of the ribosomal RNA intervening sequence. Cell 31:147-157

Lorsch JR, Szostak JW (1994a) In vitro evolution of new ribozymes with polynucleotide kinase activity. Nature 371:31-36

Lorsch JR, Szostak JW (1994b) In vitro selection of RNA aptamers specific for cyanocobalamin. Biochemistry 33:973-982

Michel F, Hanna M, Green R, Bartel DP, Szostak JW (1989) The guanosine binding site of the Tetrahymena ribozyme. Nature 342 : 391-395

Miller SL, Schlesinger G (1993a) Prebiotic syntheses of vitamin coenzymes: 1. Cysteamine and 2-mercaptoethanesulfonic acid (coenzyme M). J Mol Evol 36:308-314

Miller SL, Schlesinger G (1993b) Prebiotic syntheses of vitamin coenzymes: II. Pantoic acid, pantothenic acid, and the composition of coenzyme A. J Mol Evol 36:308-314

Mörl M, Niemer I, Schmelzer C (1992) New reactions catalyzed by a group II intron ribozyme with RNA and DNA substrates. Cell 70:803-810

Nadeau JG, Singleton CK, Kelly GB, Weith HL, Gough GR (1984) Use of ribonucleosides as protecting groups in synthesis of polynucleotides with phosphorylated terminals. Biochemistry 23:61536159

Noller HF, Hoffarth V. Zimniak L (1992) Unusual resistance of pep- 
tidyl transferase to protein extraction procedures. Science 256: 1416-1419

Orgel LE (1968) Evolution of the genetic apparatus. J Mol Biol 38: 381-393

Piccirilli JA, McConnell TS, Zaug AJ, Noller HF, Cech TR (1992) Aminoacyl esterase activity of the Tetrahymena ribozyme. Science 256: 1420-1424

Prudent JR, Uno T, Schultz PG (1994) Expanding the scope of RNA catalysis. Science 264:1924-1927

Sassanfar M, Szostak JW (1993) An RNA motif that binds ATP. Nature 364:550-553

Symons RH (1992) Small catalytic RNAs. Annu Rev Biochem 61:641671
Szostak JW (1992) In vitro genetics. Trends Biochem Sci 17:89-93

Wang JF, Cech TR (1992) Tertiary structure around the guanosinebinding site of the Terrahymena ribozyme. Science 256:526-529

Watson JD, Hopkins NH, Roberts JW, Steitz JA, Weiner AM (1987) Molecular biology of the gene. 4th ed. Benjamin/Cummings, Menlo Park, pp 1103-1127

White HB (1976) Coenzymes as fossils of an earlier metabolic state. J Mol Evol 7:101-104

Woese CR (1967) The genetic code, chapter 7, Harper and Row, New York

Zaug AJ, Been MD, Cech TR (1986) The Tetrahymena ribozyme acts like an RNA restriction endonuclease. Nature 324:429-433 